\title{
THE ROLE OF SALIVARY AND SERUM CA125 AND ROUTINE BLOOD TESTS IN PATIENTS WITH OVARIAN MALIGNANCIES
}

\author{
Ante Vuković ${ }^{1}$, Krunoslav Kuna ${ }^{1}$, Božana Lončar Brzak ${ }^{2},{ }^{\dagger}$ Vanja Vučičević Boras ${ }^{2}$, \\ Robert Šeparović ${ }^{3}$, Mario Šekerija ${ }^{4}$, Lada Sumilin $^{5}$ and Valentina Vidranski ${ }^{6}$ \\ ${ }^{1}$ Department of Gynecology and Obstetrics, Sestre milosrdnice University Hospital Centre, \\ Zagreb, Croatia; \\ ${ }^{2}$ Department of Oral Medicine, School of Dental Medicine, University of Zagreb, Zagreb, Croatia; \\ ${ }^{3}$ University Hospital for Tumors, Sestre milosrdnice University Hospital Centre, Zagreb, Croatia; \\ ${ }^{4}$ Croatian Institute of Public Health, Zagreb, Croatia; \\ ${ }^{5}$ Aviva Polyclinic, Zagreb, Croatia; \\ ${ }^{6}$ Department of Nuclear Medicine, Sestre milosrdnice University Hospital Centre, Zagreb, Croatia
}

SUMMARY - The use of routine blood tests has recently been shown to be promising in determining disease-free and overall survival in patients with various malignancies, and also in gynecologic malignancies. The aim of this study was to evaluate whether salivary and serum CA125 levels correlate and whether salivary and serum CA125, C-reactive protein and routine blood tests might serve as a prognostic factor in malignant ovarian tumors, and whether they might differentiate between benign and malignant ovarian tumors. A total of 98 women were included (48 with benign ovarian tumors and 50 with malignant ovarian tumors), in whom routine blood tests were made and salivary and serum CA125 levels were determined by use of ELISA. Increase in serum CA125 and amylase decreased overall survival, whereas increase in salivary CA125, potassium levels and hemoglobin increased overall survival. Significant correlation of serum CA125 and C-reactive protein was found in the group with malignant tumors. In conclusion, significant increase in the levels of serum CA125 and amylase correlated with decreased survival, whereas increased salivary CA125, hemoglobin and potassium levels significantly correlated with increased survival.

Key words: Malignancies; CA125 antigen; Blood tests

\section{Introduction}

Recent publications highlight a greater role of common blood tests in patients with various cancers than previously assumed. Malignant tumors are often accompanied by a higher risk of hematologic abnormalities. Recent studies have shown that the presence of systemic inflammation correlates with poorer dis-

Correspondence to: Assist. Prof. Božana Lončar Brzak, DMD, PhD, Department of Oral Medicine, School of Dental Medicine, University of Zagreb, Gundulićeva 5, HR-10000 Zagreb, Croatia E-mail: bozana.loncar@gmail.com

Received May 30, 2019, accepted June 7,2019 ease-free and overall survival in cancer patients ${ }^{1-3}$. Anemia, hemoglobinemia, thrombocytosis and leukocytosis are thought to be adverse prognostic factors in various malignancies. Thrombocytosis, leukocytosis and anemia have been demonstrated to be independent poor prognostic factors in ovarian, endometrial and uterine serous papillary carcinoma. It is known that over $20 \%$ of ovarian cancer patients have preoperative thrombocytosis or hyperfibrinogenemia ${ }^{4}$. Furthermore, we assumed that salivary and serum CA125 levels might differentiate benign from malignant ovarian masses as salivary samples are easier to collect, cheaper and noninvasive. 


\section{Materials and Methods}

This study was approved by the Ethics Committee of the School of Dental Medicine, University of $\mathrm{Za}^{-}$ greb, Zagreb, Croatia. All participants signed informed consent according to Helsinki II. A total of 98 women treated at Sestre milosrdnice University Hospital Centre were included in the study. Of them, 48 had benign ovarian tumors and 50 malignant ovarian tumors. In all patients, saliva and serum were collected for determination of CA125. Routine blood tests were made in all patients.

Saliva was collected according to Wu Wang et al. ${ }^{5}$ over five minutes at 8-10 AM into calibrated test tubes, while participants were sitting. Saliva samples were delivered to laboratory within 30 minutes after sampling and immediately frozen-stored at $-20{ }^{\circ} \mathrm{C}$. On the day of assay, the samples were thawed, vortexed and centrifuged for 15 minutes at $396 \mathrm{xg}$ on a Rotina 35R centrifuge (Hettich, Kirchlengern, Germany). Peripheral blood samples were collected by venipuncture in two Vaccuete ${ }^{\circledR}$ red cap serum tubes with clot activator (Greiner Bio-One, Kremsmünster, Austria). Blood for serum testing was centrifuged for 10 minutes at 4 ${ }^{\circ} \mathrm{C}$ and $2150 \mathrm{~g}$ on a benchtop centrifuge.

From one tube, $\mathrm{C}$-reactive protein (CRP), calcium and amylase were instantly determined in sera. CRP was determined by immunoturbidimetry, calcium and amylase by photometry, all on an Architect c8000 clinical chemistry analyzer (Abbott, IL, USA). The recommended reference values for CRP, calcium and amylase are: $<5 \mathrm{ng} / \mathrm{L}, 2.10-2.55 \mathrm{mmol} / \mathrm{L}$ and $25-125 \mathrm{U} / \mathrm{L}$, respectively.

From the other tube, two aliquots $(2 \times 0.5 \mathrm{~mL})$ of serum samples were immediately frozen at $-20{ }^{\circ} \mathrm{C}$ until analysis of tumor markers. At the time of determination, aliquots were defrosted by leaving them at room temperature until liquid state.

The CA125 tumor marker was measured in serum and in saliva on an Immulite 1000 automatic immunochemistry analyzer (Siemens Healthcare Diagnostics, Erlangen, Germany) by the chemiluminescent enzyme immunometric method using original Siemens reagents and adjustors according to the manufacturers' instructions. The calibration range for CA125 is 500 $\mathrm{kIU} / \mathrm{L}$ with analytical sensitivity $0.2 \mathrm{kIU} / \mathrm{L}$. The recommended cut-off value for serum samples in women is $18 \mathrm{kIU} / \mathrm{L}$ (95\%).
Statistical analysis was performed using the STATISTICA version 12 (StatSoft, Inc., Tulsa, OK, USA) software and MedCalc version 19 (MedCalc Software, Ostend, Belgium; https://www.medcalc.org; 2019). Categorical variables were expressed as number and percentage (\%). Quantitative variables were tested for normality of distribution by use of KolmogorovSmirnov test and expressed as arithmetic mean (M) and standard deviation (SD) or as median or interquartile range (IQR), depending on the type of distribution. Difference between the groups for quantitative variables was tested with Mann-Whitney U-test. The correlation between two tested CA125 measurements (serum and saliva) was tested with Spearman correlation analysis, concordance test and Bland-Altman analysis together with graphic presentation. The correlation of salivary and serum CA125 with other variables in the two groups (benign and malignant) was tested with Spearman correlation analysis. ROC analysis was used for CA125 predictability (serum and saliva) for malignant disease under the curve (AUC) with $95 \%$ confidence interval $(95 \% \mathrm{CI})$, sensitivity and specificity, positive and negative ratio for diagnosis (+LR, -LR) with 95\% CI for various borderline values. Kaplan-Meier analysis was used for overall survival in patients with malignant disease. Overall survival was the time from the diagnosis until death. The correlation between overall survival and potential predictors (independent variables) was assessed by Cox regression analysis and the results were expressed as hazard ratio and $95 \% \mathrm{CI}$. In all analyses, the level of statistical significance was set at $\mathrm{p}<0.05$.

\section{Results}

The study included 98 women (48 with benign tumors and 50 with malignant tumors) in whom saliva and serum were collected for CA125 determination. Patient characteristics are shown in Table 1 . The group with malignant tumors was significantly older than the group with benign tumors $(59.3 \pm 14.5$ years vs. $46.9 \pm 16.24$ years, $p<0.001)$ and had significantly higher salivary CA125 levels (median (IQR), $>500$ ( $>500$ $>500)$ vs. $>500(252->500) \mathrm{kIU} / \mathrm{L}, \mathrm{p}=0.017)$, serum CA125 levels (median (IQR), 491.7 (145.7-855.0) vs. 28.1 (12.1-66.1) kIU/L, p<0.001) and CRP levels (median (IQR), 23.1 (7.2-62.6) vs. 3.10 (1.35-4.85) $\mathrm{mg} / \mathrm{L}, \mathrm{p}<0.001)$. In addition, patients with malignant 
Table 1. Patient characteristics ( $N=98)$

\begin{tabular}{|c|c|c|c|c|c|c|}
\hline \multirow{2}{*}{ Variable } & \multicolumn{2}{|r|}{ Benign tumors } & \multicolumn{2}{|r|}{ Malignant tumors } & \multicolumn{2}{|c|}{ Statistics } \\
\hline & $\mathrm{n}$ & $\mathrm{M} \pm \mathrm{SD}^{*}$ & $\mathrm{n}$ & $\mathrm{M} \pm \mathrm{SD}^{*}$ & Z & $\mathrm{p}$-value \\
\hline Year of birth & 48 & [1931-2001] & 50 & {$[1935-1992]$} & 3.678 & $<0.001$ \\
\hline Age (yrs) & 48 & $46.9 \pm 16.24$ & 50 & $59.3 \pm 14.5$ & -3.678 & $<0.001$ \\
\hline $\begin{array}{l}\text { CA125 saliva } \\
\text { (kIU/L) }\end{array}$ & 48 & $>500(252->500)[9.6->500]$ & 50 & $>500(>500->500)[38.4->500]$ & -2.379 & 0.017 \\
\hline $\begin{array}{l}\text { CA125 serum } \\
(\mathrm{kIU} / \mathrm{L})\end{array}$ & 48 & $28.1(12.1-66.1)[4.5->500]$ & 50 & $491.7(145.7-855.0)$ [9.6-10000] & -5.590 & $<0.001$ \\
\hline $\begin{array}{l}\text { Red blood cells } \\
\left(10^{12} / \mathrm{L}\right)\end{array}$ & 48 & $4.39 \pm 0.46$ & 50 & $4.25 \pm 0.52$ & 1.620 & 0.105 \\
\hline Hemoglobin $(\mathrm{g} / \mathrm{L})$ & 48 & $132 \pm 14$ & 50 & $122 \pm 14$ & 3.642 & $<0.001$ \\
\hline Leukocytes $\left(10^{9} / \mathrm{L}\right)$ & 47 & $7.33 \pm 2.37$ & 50 & $9.35 \pm 2.63$ & -4.136 & $<0.001$ \\
\hline Platelets $\left(10^{9} / \mathrm{L}\right)$ & 47 & $240 \pm 72$ & 49 & $333 \pm 116$ & -4.551 & $<0.001$ \\
\hline Potassium (mmol/L) & 47 & $4.2 \pm 0.4$ & 50 & $4.4 \pm 0.5$ & -1.617 & 0.106 \\
\hline Sodium (mmol/L) & 15 & $140 \pm 2.5$ & 29 & $137 \pm 6$ & 1.300 & 0.194 \\
\hline Chloride (mmol/L) & 15 & $105 \pm 2$ & 26 & $104 \pm 4$ & 0.866 & 0.386 \\
\hline Calcium (mmol/L) & 44 & $2.40 \pm 0.11$ & 49 & $2.37 \pm 0.20$ & 1.931 & 0.053 \\
\hline Amylase (U/L) & 47 & $55 \pm 22$ & 48 & $56.5(42.0-65.0)$ [13-1304] & -0.618 & 0.537 \\
\hline $\begin{array}{l}\text { C-reactive protein } \\
(\mathrm{mg} / \mathrm{L})\end{array}$ & 48 & $3.10(1.35-4.85)$ & 50 & $23.1(7.2-62.6)$ & -6.101 & $<0.001$ \\
\hline
\end{tabular}

*data are presented as arithmetic mean $(\mathrm{M}) \pm$ standard deviation $(\mathrm{SD})$ or as median (interquartile range) and/or range.

tumors had significantly higher leukocyte and platelet count $(\mathrm{p}<0.001$ both) and lower hemoglobin level $(\mathrm{p}<0.001)$. Other parameters were comparable in the two patient groups (red blood cell (RBC) count, potassium, sodium, chloride and calcium levels ( $\mathrm{p}>0.05$ all) and amylase $(\mathrm{p}=0.537)$.

There was no significant correlation between salivary and serum CA125 in the whole sample $(\mathrm{N}=98$; $\mathrm{R}=-0.006 ; \mathrm{p}=0.953$; Spearman correlation analysis) or coincidence of the results $(\mathrm{CCC}=-0.065$; 95\% CI $=-$ $0.177-0.049$ ). Bland-Altman analysis revealed significant disparity of the results (Fig. 1), where linear dependence (increase) of serum and salivary CA125 was noticed in serum.

Analysis of salivary and serum CA125 in patients with malignant tumors $(n=44)$ showed the same pattern $(\mathrm{R}=0.087$; $\mathrm{p}=0.575$; Spearman correlation analysis) of incompatibility as in the whole sample, whereas in the group with benign tumors $(n=47)$ slight significance was obtained which was inversely related to salivary and serum CA125 ( $R=-0.415 ; \mathrm{p}=0.004$; Spearman correlation analysis) (Fig. 2). The increase in serum CA125 correlated with decreased salivary CA125.

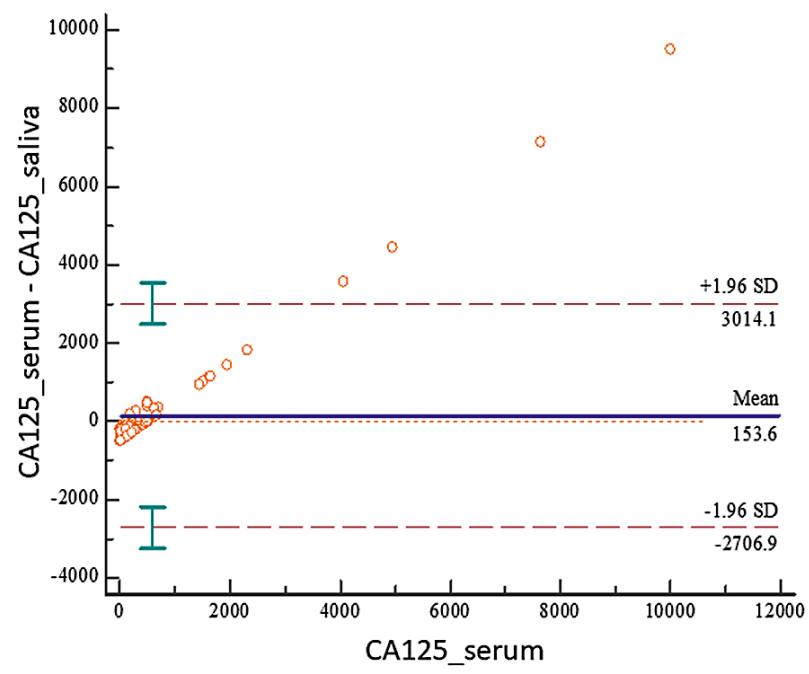

Fig. 1. Bland-Altman plot comparisons of salivary and serum CA125.

Tables 2 and 3 show significant correlation between serum CA125 and age in patients with benign and malignant ovarian tumors, i.e. negative correlation in patients with benign tumors $(\mathrm{R}=-0.299, \mathrm{p}=0.041)$ and positive correlation in patients with malignant tu- 


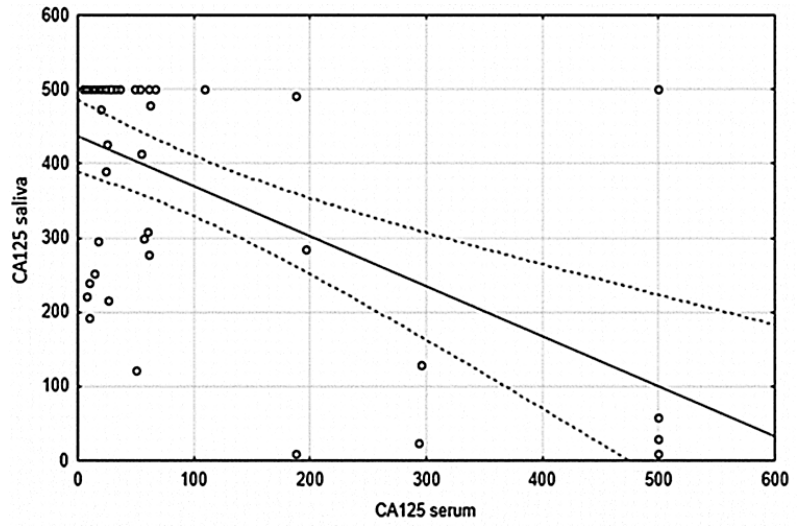

Fig. 2. Scattering of the correlation between salivary and serum CA125 in the group of benign tumors $(n=47 ; R=-0.415 ; p=0.004 ;$ Spearman correlation analysis).

Table 2. Correlation of salivary and serum CA125 with age and laboratory measurements in the group with benign tumors

\begin{tabular}{|l|l|l|l|}
\hline & $\mathrm{n}$ & $\mathrm{R}$ & $\mathrm{p}$-value \\
\hline CA125 saliva/age & 47 & 0.277 & 0.060 \\
CA125 saliva/red blood cells & 47 & 0.356 & $\mathbf{0 . 0 1 4}$ \\
CA125 saliva/hemoglobin & 47 & $\mathbf{0 . 3 5 1}$ & $\mathbf{0 . 0 1 6}$ \\
CA125 saliva/leukocytes & 46 & 0.046 & 0.761 \\
CA125 saliva/platelets & 46 & -0.013 & 0.931 \\
CA125 saliva/potassium & 46 & 0.117 & 0.441 \\
CA125 saliva/sodium & 15 & -0.126 & 0.654 \\
CA125 saliva/chloride & 15 & 0.022 & 0.937 \\
CA125 saliva/calcium & 43 & 0.062 & 0.693 \\
CA125 saliva/amylase & 46 & 0.208 & 0.165 \\
CA125 saliva/C-reactive protein & 47 & 0.097 & 0.516 \\
CA125 serum/age & 47 & -0.299 & 0.041 \\
CA125 serum/red blood cells & 47 & 0.004 & 0.978 \\
CA125 serum/hemoglobin & 47 & -0.161 & 0.279 \\
CA125 serum/leukocytes & 46 & 0.058 & 0.704 \\
CA125 serum/platelets & 46 & -0.106 & 0.483 \\
CA125 serum/potassium & 46 & 0.143 & 0.344 \\
CA125 serum/sodium & 15 & -0.151 & 0.592 \\
CA125 serum/chloride & 15 & 0.073 & 0.795 \\
CA125 serum/calcium & 43 & -0.073 & 0.642 \\
CA125 serum/amylase & 46 & -0.125 & 0.407 \\
CA125 serum/C-reactive protein & 47 & 0.240 & 0.105 \\
\hline
\end{tabular}

Data are expressed as number of participants (n); $R=$ Spearman correlation coefficient mors $(\mathrm{R}=0.307, \mathrm{p}=0.034)$. In patients with benign tumors, there was significant correlation of salivary CA125 with $\mathrm{RBC}$ count $(\mathrm{R}=0.356, \mathrm{p}=0.014)$ and hemoglobin values $(R=0.351, p=0.016)$. In the group with malignant tumors, there was significant correlation between serum CA125 and CRP $(\mathrm{R}=0.484$, $\mathrm{p}<0.001)$. All these significant correlations were weak. All other laboratory measurements yielded no significant correlation with salivary and serum CA125 in either patient group (Tables 2 and 3).

In order to predict serum CA125 in patients with malignant disease, ROC analysis for group comparison was performed and yielded significant differences by AUC from 0.833 (95\% CI, 0.743-0.902, $\mathrm{z}=7.918 ; \mathrm{p}<0.001)$ with difference criteria of $>109$ $\mathrm{kIU} / \mathrm{L}$ CA125 with $79.17 \%$ sensitivity (95\% CI, 65.0-

Table 3. Correlation of salivary and serum CA125 with age and laboratory measurements in the group with malignant tumors

\begin{tabular}{|l|l|l|l|}
\hline & $\mathrm{n}$ & $\mathrm{R}$ & $\mathrm{p}$-value \\
\hline CA125 saliva/age & 44 & -0.239 & 0.118 \\
CA125 saliva/red blood cells & 44 & 0.200 & 0.193 \\
CA125 saliva/hemoglobin & 44 & 0.153 & 0.323 \\
CA125 saliva/leukocytes & 44 & -0.054 & 0.729 \\
CA125 saliva/platelets & 43 & 0.036 & 0.817 \\
CA125 saliva/potassium & 44 & 0.006 & 0.967 \\
CA125 saliva/sodium & 24 & -0.336 & 0.109 \\
CA125 saliva/chloride & 21 & 0.034 & 0.883 \\
CA125 saliva/calcium & 43 & 0.146 & 0.350 \\
CA125 saliva/amylase & 42 & -0.104 & 0.514 \\
CA125 saliva/C-reactive protein & 44 & -0.079 & 0.609 \\
CA125 serum/age & 48 & $\mathbf{0 . 3 0 7}$ & $\mathbf{0 . 0 3 4}$ \\
CA125 serum/red blood cells & 48 & -0.034 & 0.819 \\
CA125 serum/hemoglobin & 48 & -0.139 & 0.347 \\
CA125 serum/leukocytes & 48 & 0.205 & 0.162 \\
CA125 serum/platelets & 47 & 0.202 & 0.173 \\
CA125 serum/potassium & 48 & 0.097 & 0.513 \\
CA125 serum/sodium & 27 & -0.163 & 0.416 \\
CA125 serum/chloride & 24 & 0.172 & 0.423 \\
CA125 serum/calcium & 47 & -0.079 & 0.599 \\
CA125 serum/amylase & 46 & 0.122 & 0.421 \\
CA125 serum/C-reactive protein & 48 & $\mathbf{0 . 4 8 4}$ & $\mathbf{0 . 0 0 0}$ \\
\hline
\end{tabular}

Data are expressed as number of participants (n); $R=$ Spearman correlation coefficient 


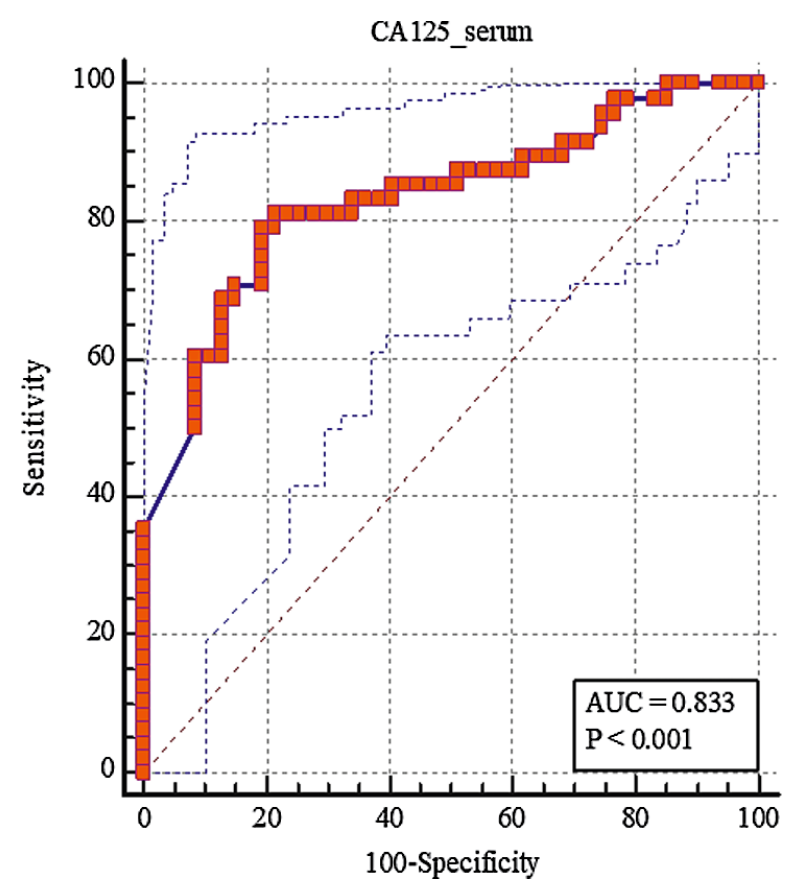

Fig. 3. ROC curve of sensitivity/specificity for serum CA125.

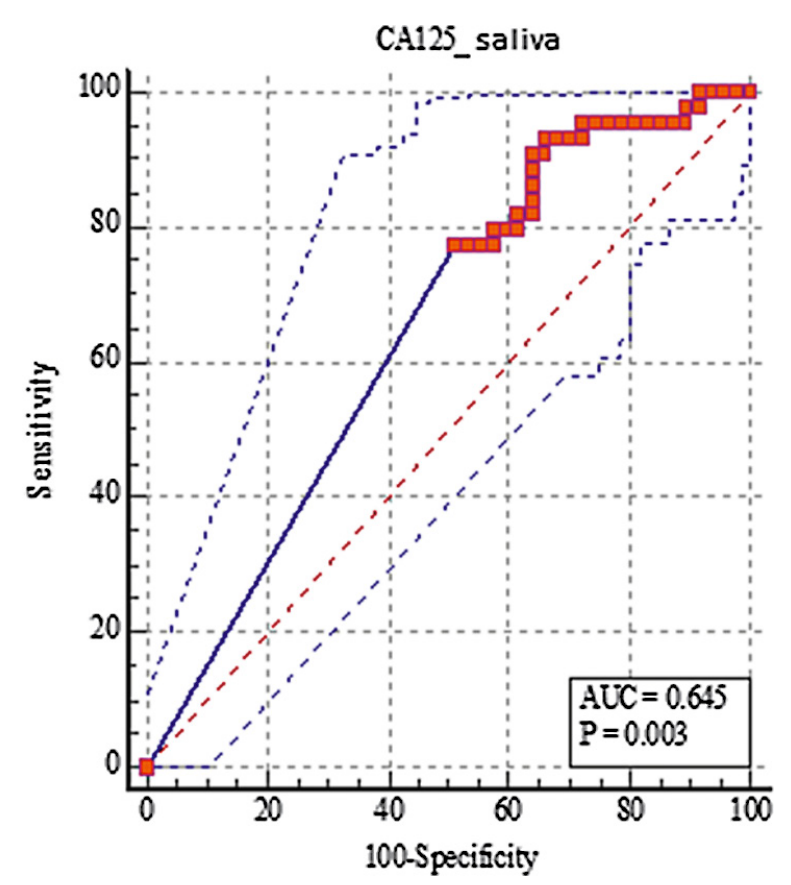

Fig. 4. ROC curve of sensitivity/specificity for salivary CA125.

Table 4. Prediction variables that significantly correlated with overall survival in patients with malignant tumors $(N=50)$

\begin{tabular}{|l|l|l|l|l|l|l|}
\hline Covariable & $\mathrm{b}$ & $\mathrm{SE}$ & Wald & $\mathrm{p}$-value & $\operatorname{Exp}(\mathrm{b})$ & $95 \%$ CI for $\operatorname{Exp}(\mathrm{b})$ \\
\hline CA125 serum $(\mathrm{kIU} / \mathrm{L})$ & 0.00038 & 0.0002 & 6.177 & 0.013 & 1.001 & 1.0001 to 1.0007 \\
CA125 saliva (kIU/L) & -0.00737 & 0.0024 & 9.571 & 0.002 & 0.993 & 0.9880 to 0.9973 \\
Amylase $(\mathrm{U} / \mathrm{L})$ & 0.00847 & 0.0034 & 6.094 & 0.014 & 1.009 & 1.0017 to 1.0153 \\
Hemoglobin $(\mathrm{g} / \mathrm{L})$ & -0.04096 & 0.0203 & 4.059 & 0.044 & 0.960 & 0.9224 to 0.9989 \\
Potassium $(\mathrm{mmol} / \mathrm{L})$ & -1.13840 & 0.4754 & 5.734 & 0.017 & 0.320 & 0.1262 to 0.8133 \\
\hline
\end{tabular}

$\mathrm{b}=$ regression coefficient; $\mathrm{SE}=$ standard error; Wald = results of Wald statistics; $\operatorname{Exp}(\mathrm{b})=$ hazard ratio $(\mathrm{HR}) ; 95 \% \mathrm{CI}$ for $\operatorname{Exp}(\mathrm{b})=95 \%$ confidence interval for HR

$89.5 \%)$ and $80.85 \%$ specificity (95\% CI, 66.7-90.9\%) (Fig. 3).

In order to determine salivary CA125 predictability in malignant tumors, ROC analysis was performed by comparison of the groups and significant differences were determined by AUC of 0.645 (95\% CI, 0.538-0.743, z=2.94; $\mathrm{p}=0.003$ ) (Fig. 4).

Predictability of serum CA125 was significantly better when compared to salivary CA125 $(p<0.05)$, with significantly better specificity $(\mathrm{p}<0.05)$.

Overall survival analysis showed that median overall survival in patients with malignant disease was 21.9 months (IQR 3.39, unknown) with 95\% CI of 11.6-
44.7 months. Cox regression analysis showed a model that significantly predicted survival $\left(\chi^{2}-=32.305, \mathrm{df}=5\right.$; $\mathrm{p}<0.001)$. Significantly independent predictive variables for overall survival were CA125 in serum and saliva, amylase, hemoglobin and potassium (Table 4). Increase in serum CA125 by every kIU/L decreased overall survival by $0.1 \%$ (HR 1.001, p=0.013). Increase in salivary CA125 by every $\mathrm{kIU} / \mathrm{L}$ increased overall survival by $0.7 \%$ (HR $0.993, p=0.002)$. Increase in amylase by every $\mathrm{U} / \mathrm{L}$ decreased overall survival by $0.9 \%$ (HR 1.009, $\mathrm{p}=0.013$ ). Increase in hemoglobin by every $\mathrm{g} / \mathrm{L}$ increased overall survival by $4 \%$ (HR 0.960 , $\mathrm{p}=0.044)$. Increase in potassium levels by every 
$\mathrm{mmo1} / \mathrm{L}$ increased overall survival by $78 \%$ (HR 0.320 , $\mathrm{p}=0.017)$.

\section{Discussion}

Younes et al. ${ }^{4}$ found that leukocytosis and neutrophilia significantly correlated with aggressive tumor biology and may predict a lower 5-year survival. Their study was performed in 56 women and the results showed that leukocyte and neutrophil levels were adversely associated with survival. Of 15 patients with leukocytosis $>10000 / \mu \mathrm{L}, 67 \%$ were dead at the end of follow up, and of 27 patients with neutrophils above $65 \%, 14(52 \%)$ were dead at the end of follow up. These findings are not in concordance with ours where leukocytosis did not correlate with shorter overall survival. However, in our study, leukocytosis was more prevalent in patients with malignant in comparison to patients with benign ovarian masses. Feng et al. ${ }^{6}$ analyzed 875 patients and report that both preoperative thrombocytosis and hyperfibrinogenemia were associated with an advanced Fédération Internationale de Gynécologie et d'Obstétrique (FIGO) stage of ovarian cancer, elevated CA125 level, more extensive ascites, more extensive residual disease, and chemosensitivity. However, thrombocytosis was not found to be a potential predictor of disease-free and overall survival, which is in concordance with the results of our study. Słabuszewska-Jóźwiak et al. ${ }^{7}$ reviewed 349 patients with ovarian tumor and defined thrombocytopenia when platelet count was below $150 \mathrm{G} / \mathrm{L}$ and thrombocythemia when platelets were at $350 \mathrm{G} / \mathrm{L}$ and higher. Thrombocytosis often coincides with ascites and cytoreduction decreases platelet count. Thrombocytosis was more frequently found in high grade tumors and in stage III and IV cancers. Patients with co-occurring thrombocytosis were found to have shorter survival periods and shorter disease-free period. This finding was also contradictory to our finding as we found no differences regarding thrombocytosis and overall survival in our patients with malignant ovarian tumors. Yilmaz et al. ${ }^{8}$ found serum CA125 levels to be increased only in one-third of patients with 1A FIGO stage of borderline ovarian tumors, while Seckin et al. ${ }^{9}$ found that CA19-9, neutrophil/lymphocyte ratio (NLR) and CA125 were significant predictors of malignancy in patients who had an intraoperative frozen section diagnosis of borderline mucinous ovarian tu- mors. Patient age, menopausal status, hemoglobin, platelet and lymphocyte counts were not different between the groups. However, white blood cell and neutrophil counts, NLR, CA125 and CA19-9 were significantly higher in malignant cases. This finding is partially in concordance with our results as we also found increased white blood cell count and CA125 in patients with malignant tumors. Utsumi et al. ${ }^{10}$ reviewed 77 charts of terminally ill patients with ovarian cancer and concluded that poorer performance status, elevated white blood cell count and higher CRP value significantly correlated with shorter survival. This is partially in concordance with the results of our study, which revealed significant correlation of higher CRP and shorter overall survival. Chen et al. ${ }^{11}$ report that preoperative anemia, leukocytosis or thrombocytosis in epithelial ovarian cancer (EOC) patients is closely associated with a more malignant disease phenotype and poorer prognosis. Significantly, thrombocytosis may independently predict disease-specific survival in EOC patients. Their results were based on $816 \mathrm{Chi}-$ nese women. This finding is contrary to ours, as we found no correlation between thrombocytosis and overall survival in patients with malignant ovarian tumors. So et al. ${ }^{12}$ analyzed 155 women, 23 (14.8\%) of them with leukocytosis and 132 (85.2\%) without leukocytosis. Recurrence-free survival and overall survival were significantly shorter in women with leukocytosis than in those without leukocytosis. The mortality rate was also higher among women with leukocytosis. The same authors ${ }^{12}$ conclude that preoperative leukocytosis might be an independent prognostic factor for recurrence-free survival and overall survival in women with EOC. This was not confirmed in our study as preoperative leukocytosis did not correlate with overall survival in patients with malignant ovarian tumors. $\mathrm{Co}^{-}$ hen et al. ${ }^{13}$ reviewed 107 women with invasive EOC and thrombocytosis was determined as platelet count $\geq 350 \times 10^{9} / \mathrm{L}$ and optimal resection at secondary cytoreductive surgery as microscopic residual disease. The same authors ${ }^{13}$ report that elevated platelet count at the time of secondary cytoreductive surgery is associated with suboptimal resection and shortened overall survival. Furthermore, $\mathrm{Ma}$ et al. ${ }^{14}$ also report that thrombocytosis accompanied by increasing platelet aggregation rates is associated with a more aggressive tumor biology and negative prognostic factor for overall survival in EOC patients. This finding was not con- 
firmed in our study. Thrombocytosis finding was different in patients with benign and malignant ovarian tumors; however, it was not correlated with shorter overall survival in patients with malignant ovarian masses. Nomelini et al. ${ }^{15}$ report that CA125, CA15.3, hemoglobin, and platelets might be indicators of prognosis in patients with ovarian cancer. This is partially consistent with our results as we also found serum CA125 and hemoglobin to be independent predictors of overall survival; however, platelets were not independent predictors of overall survival in patients with ovarian cancer. Contrary to these findings, Younes et $a l .^{4}$ could not confirm that hemoglobin values significantly correlated with 5-year survival. Furthermore, Altman et al. ${ }^{16}$ suggested that hemoglobin levels were weakly associated with recurrence-free survival and overall survival.

In the literature published to date, there are scarce data on salivary, serum and urinary CA125 levels in patients with these cancers. Geng et al. ${ }^{17}$ report on increased salivary CA125 levels in patients with oral cancer when compared to those with benign cancers and controls. Agha-Hosseini et al. ${ }^{18}$ report that salivary and serum CA125 were significantly increased in patients with untreated breast cancer as compared to patients with treated breast cancer and controls. Tay and $\mathrm{Chua}^{19}$ report that serum and urinary CA125 levels were significantly increased in patients with malignant ovarian cancer when compared to those with benign ovarian tumors. However, no significant differences were found regarding salivary CA125 levels in these groups, which is contrary to our findings. Chen and $\mathrm{Li}^{20}$ report that salivary CA125 had better diagnostic value when compared to serum CA125 in patients with ovarian cancer. The results of this study showed that patients with malignant tumors had significantly higher salivary and serum CA125 levels when compared to patients with benign tumors. However, there was no significant correlation between salivary and serum CA125 in the whole sample.

The results of this study showed that patients with malignant tumors were significantly older than those with benign tumors, and had significantly higher salivary and serum CA125 and CRP levels. Patients with malignant tumors also had significantly higher leukocyte and platelet counts, and lower hemoglobin level. Significantly independent predictive variables for overall survival were serum and salivary CA125, amy- lase, hemoglobin and potassium. In patients with malignant tumors, there was a significant correlation of serum CA125 and CRP. Significantly increased levels of serum CA125 and amylase correlated with decreased survival, whereas increased salivary CA125, hemoglobin and potassium levels significantly correlated with increased survival.

\section{References}

1. Toiyama Y, Inoue Y, Kawamura M, Kawamoto A, Okugawa Y, Hiro J, et al. Elevated platelet count as predictor of recurrence in rectal cancer patients undergoing preoperative chemo-radiotherapy followed by surgery. Int Surg. 2015;100(2):199-207. doi: 10.9738/INTSURG-D-13-00178.1

2. Kitayama J, Yasuda K, Kawai K, Sunami E, Nagawa H. Circulating lymphocyte is an important determinant of the effectiveness of preoperative radiotherapy in advanced rectal cancer. BMC Cancer. 2011;11:64. doi: 10.1186/1471-2407-11-64

3. Li MX, Liu XM, Zhang XF, Zhang JF, Wang WL, Dong J, et al. Prognostic role of neutrophil-to-lymphocyte ratio in colorectal cancer: a systematic review and meta-analysis. Int J Cancer. 2014;134(10):2403-13. doi: 10.1002/ijc.28536

4. Younes G, Segev Y, Begal J, Auslender R, Goldberg Y, Amit A, et al. The prognostic significance of hematological parameters in women with uterine serous papillary carcinoma (USPC). Eur J Obstet Gynecol Reprod Biol. 2016;199:16-20. doi: 10.1016/j.ejogrb.2016.01.043

5. Wu Wang CY, Patel M, Feng J, Milles M, Wang SL. Decreased levels of salivary prostaglandin E2 and epidermal growth factor in recurrent aphthous stomatitis. Arch Oral Biol. 1995;40 (12):1093-8.

6. Feng Z, Wen H, Bi R, Duan Y, Yang W, Wu X. Thrombocytosis and hyperfibrinogenemia are predictive factors of clinical outcomes in high-grade serous ovarian cancer patients. BMC Cancer. 2016;16:43. doi: 10.1186/s12885-016-2070-2

7. Słabuszewska-Jóźwiak A, Dmoch-Gajzlerska E, Kozakiewicz B, Jakiel G. The prognostic significance of thrombocytosis in ovarian cancer. Ann Agric Environ Med. 2015;22(4):731-5. doi: 10.5604/12321966.1185785

8. Yilmaz E, Sahin N, Koleli I, Melekoglu R, Tanrikut E, Faydali $\mathrm{S}$, et al. Retrospective analysis of borderline ovarian tumors: outcomes at a single center. Acta Clin Croat. 2019;58(1):29-36. doi: 10.20471/acc.2019.58.01.04

9. Seckin KD, Karslı MF, Yucel B, Bestel M, Y1ldırım D, et al. The utility of tumor markers and neutrophil lymphocyte ratio in patients with an intraoperative diagnosis of mucinous borderline ovarian tumor. Eur J Obstet Gynecol Reprod Biol. 2016; 196:60-3. doi: 10.1016/j.ejogrb.2015.10.025

10. Utsumi F, Kajiyama H, Niimi K, Sekiya R, Sakata J, Suzuki S, et al. Clinical significance and predicting indicators of postcancer-treatment survival in terminally ill patients with ova- 
rian cancer. J Obstet Gynaecol Res. 2017;43(2):365-70. doi: 10.1111/jog.13219

11. Chen Y, Zhang L, Liu WX, Liu XY. Prognostic significance of preoperative anemia, leukocytosis and thrombocytosis in Chinese women with epithelial ovarian cancer. Asian Pac J Cancer Prev. 2015;16(3):933-9.

12. So KA, Hong JH, Jin HM, Kim JW, Song JY, Lee JK, et al. The prognostic significance of preoperative leukocytosis in epithelial ovarian carcinoma: a retrospective cohort study. Gynecol Oncol. 2014;132(3):551-5. doi: 10.1016/j.ygyno.2014.01.010

13. Cohen JG, Tran AQ, Rimel BJ, Cass I, Walsh CS, Karlan BY, et al. Thrombocytosis at secondary cytoreduction for recurrent ovarian cancer predicts suboptimal resection and poor survival. Gynecol Oncol. 2014;132(3):556-9. doi: 10.1016/j.ygyno. 2014.01.003

14. Ma X, Wang Y, Sheng H, Tian W, Qi Z, Teng F, et al. Prognostic significance of thrombocytosis, platelet parameters and aggregation rates in epithelial ovarian cancer. J Obstet Gynaecol Res. 2014;40(1):178-83. doi: 10.1111/jog.12151

15. Nomelini RS, de Carvalho Oliveira LJ, Tavares-Murta BM, Murta EFC. Parameters of blood count and tumor markers: a retrospective analysis and relation to prognostic factors in ovarian cancer. Eur J Gynaecol Oncol. 2017;38(3):364-7.

16. Altman AD, Liu XQ, Nelson G, Chu P, Nation J, Ghatage P. The effects of anemia and blood transfusion on patients with stage III-IV ovarian cancer. Int J Gynecol Cancer. 2013;23 (9):1569-76. doi: 10.1097/IGC.0b013e3182a57ff6

17. Geng XF, Du M, Han JX, Zhang M, Tang XF, Xing RD. Saliva CA125 and TPS levels in patients with oral squamous cell carcinoma. Int J Biol Markers. 2013;28(2):216-20. doi: 10.5301 /jbm.5000001

18. Agha-Hosseini F, Mirzaii-Dizgah I, Rahimi A, Seilanian-Toosi M. Correlation of serum and salivary CA125 levels in patients with breast cancer. J Contemp Dent Pract. 2009;10 (6):E001-8.

19. Tay SK, Chua EK. Correlation of serum, urinary and salivary CA 125 levels in patients with adnexal masses. Ann Acad Med Singapore. 1994;23(3):311-4.

20. Chen DX, Li FQ.Primary research on saliva and serum CA125 assays for detecting malignant ovarian tumors. Zhonghua $\mathrm{Fu}$ Chan Ke Za Zhi. 1990;25(2):84-5, 123-4.

Sažetak

\title{
ULOGA SALIVARNOG I SERUMSKOG CA125 I RUTINSKIH NALAZA KRVI KOD BOLESNICA SA ZLOĆUDNIM TUMORIMA JAJNIKA
}

\author{
A. Vuković, K. Kuna, B. Lončar Brzak, V. Vučičević Boras, R. Šeparović, M. Šekerija, L. Šumilin i V. Vidranski
}

U posljednje vrijeme pokazalo se da su rutinski testovi krvi obećavajući u određivanju razdoblja bez bolesti i ukupnog preživljenja bolesnika s različitim zloćudnim bolestima, uključujući i ginekološke malignitete. Cilj ovoga istraživanja bio je procijeniti koreliraju li razine CA125 u slini i serumu te mogu li CA125, C-reaktivni protein u slini i serumu i rutinske pretrage krvi poslužiti kao prognostički čimbenik u malignim tumorima jajnika te mogu li razlikovati dobroćudne i zloćudne tumore jajnika. U istraživanje je uključeno 98 žena (48 s dobroćudnim tumorima jajnika i 50 sa zloćudnim tumorima jajnika), kod kojih su izvedene rutinske analize krvi i razine CA125 u slini i serumu primjenom testa ELISA. Povećanje serumskog CA125 i amilaze smanjuje ukupno preživljavanje, dok povećanje salivarnog CA125, razine kalija i hemoglobina povećava ukupno preživljavanje. U skupini sa zloćudnim tumorima zabilježena je značajna korelacija serumskog CA125 s C-reaktivnim proteinom. Može se zaključiti da su značajno povišene razine CA125 i amilaze u serumu bile u korelaciji sa smanjenim preživljenjem, dok je povišena razina CA125, hemoglobina i kalija značajno povezana s povećanim preživljenjem.

Ključne riječi: Maligniteti; CA125 antigen; Krone pretrage 